\title{
SISTEM INVENTORY BRIKET BATU BARA PT. MANDIRI MENGGUNAKAN VISUAL BASIC.NET
}

\author{
Rute Adeya Saputra ${ }^{1)}$, Khairil $^{2)}$, Ricky Zulfiandry ${ }^{2)}$ \\ ${ }^{1,2,3)}$ Program Studi Sistem Informasi Fakultas IImu Komputer Universitas \\ Dehasen Bengkulu
}

\author{
Email : ${ }^{2}$ khairil@unived.ac.id; ${ }^{3)}$ ricky.zulfiandry@unived.id
}

\author{
How to Cite : \\ Rute Adeya Saputra, Khairil, Ricky Zulfiandry.2020. Sistem Inventory Briket Batu Bara Pt. Mandiri \\ Menggunakan Visual Basic.Net. GATOTKACA Journal. DOI: \\ https://Doi.Org/10.37638/gatotkaca.1.2.164-176
}

\section{ARTICLE HISTORY}

Received [8 Oktober 2020]

Revised [16 November 2020]

Accepted [30 Desember 2020]

\section{KEYWORDS}

Sistem Inventori, Briket Batu Bara, Visual Basic.Net

This is an open access article under the $C C-B Y-S A$ license

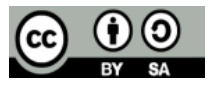

\section{ABSTRAK}

Inventory atau persediaan bukan merupakan hal yang asing lagi bagi setiap perusahaan. Namun masalah inventory terkadang masih menjadi salah satu kendala untuk mencapai tujuan perusahaan, karena sistem inventory yang tidak terkendali dan tidak adanya pengawasan yang benar serta metode yang dapat dijalankan dengan baik. PT. Bengkulu Mandiri mempunyai bidang yang bergerak dalam penjualan briket batu bara. Dalam menjalankan usahanya masih menggunakan sistem manual dengan cara memasukan data-data ke dalam buku. Untuk menghindari persediaan yang berlebihan maka seharusnya perusahaan ini membutuhkan sistem inventory yang berbasis komputer untuk membantu meningkatkan kualitas yang dibutuhkan oleh perusahaan dan mencegah terjadinya penumpukan persediaan.Implementasi sistem menggunakan bahasa pemrograman Visual Basic.Net dan metode penelitian yang digunakan pada penelitian ini adalah metode waterfall.metode waterfall mampu melakukan analisa kebutuhan yang digunakan untuk mengetahui dari kelemahan sistem yang lama, kemudian membuat desain dari rancangan tersebut dan dilanjutkan dengan pembuatan rancangan sistem baru. Hasil dari penelitian adalah aplikasi inventori ini diharapkan dapat memberikan kemudahan bagi petugas dalam melakukan kontrol serta dapat membantu proses pengelolaan transaksi pembelian, proses produksi dan transaksi penjualan melalui fungsi otomatisasi, sehingga proses pengelolaan lebih efektif dan efisien.

\section{ABSTRACT}

Inventory is not a strange thing for every company. But inventory problems are sometimes still one of the obstacles to achieving company goals, due to an uncontrolled inventory system and the lack of proper supervision and methods that can be run properly. PT. Bengkulu Mandiri has a field that is

164 | Rute Adeya Saputra ${ }^{1)}$, Khairii'), Ricky Zulfiandry'), Sistem Inventory Briket Batu Bara Pt.Mandiri.... 


\section{EAMTOT RAC/A}

engaged in the sale of coal briquettes. In carrying out its business, it still uses a manual system by entering data into books. To avoid excessive inventory, this company should need a computer-based inventory system to help improve the quality needed by the company and prevent inventory buildup. The system implementation uses the Visual Basic.Net programming language and the research method used in this study is the waterfall method. the waterfall method is able to analyze the needs that are used to find out the weaknesses of the old system, then make the design of the design and proceed with making a new system design. The results of this research are the application of inventory is expected to provide convenience for officers in controlling and can help the process of purchasing transaction management, production processes and sales transactions through the automation function, so that the management process is more effective and efficient.

\section{PENDAHULUAN}

Inventory atau persediaan bukan merupakan hal yang asing lagi bagi setiap perusahaan. Namun masalah inventory terkadang masih menjadi salah satu kendala untuk mencapai tujuan perusahaan, karena sistem inventory yang tidak terkendali dan tidak adanya pengawasan yang benar serta metode yang dapat dijalankan dengan baik. Semakin pesatnya kemajuan teknologi sekarang ini, pengunaan komputer sudah menjadi suatu kebutuhan di dalam dunia bisnis maupun kehidupan sehari-hari.

Kegunaan komputer sebagai salah satu alat pengolahan data secara elektronik merupakan suatu tindakan yang tepat dalam era kemajuan teknologi informasi dan telekomonikasi. Karena komputer diciptakan untuk membantumenyelesaikan pekerjaan manusia dalam membantu memecahkan suatu permasalahn pengolahan data. Demikian juga pada persediaaan merupakan salah satu aset yang penting bagi suatu entitas baik bagi perusahaan ritel, manufaktur, jasa, maupun entitas lainnya. Persediaan yang berlebihan akan merugikan perusahaan. Ini berarti banyak biaya yang dikeluarkan dari biaya-biaya yang ditimbulkan dengan adanya persediaan tersebut, yang mana biaya dari pembelian itu sebenarnya dapat digunakan untuk keperluan lain yang lebih menguntungkan.

Persediaan barang diartikan sebagai barang yang diperoleh perusahaan untuk dijual kembali atau diolah lebih lanjut dalam rangka menjalankan kegiatan perusahaan. Masalah persediaan merupakan masalah yang sangat penting bagi sebuah perusahaan. Tanpa adanya persediaan, perusahaan akan dihadapkan pada suatu resiko dimana perusahaan tidak dapat memenuhi keinginan pelanggan yang membutuhkan barang maupun jasa yang dihasilkan oleh perusahaan. PT. Bengkulu Mandiri mempunyai bidang yang bergerak dalam penjualan briket batu bara. Dalam menjalankan usahanya masih menggunakan sistem manual dengan cara memasukan data-data ke dalam buku. Untuk menghindari persediaan yang berlebihan maka seharusnya perusahaan ini membutuhkan sistem inventory yang berbasis komputer untuk membantu meningkatkan kualitas yang dibutuhkan oleh perusahaan dan mencegah terjadinya penumpukan persediaan.

\section{LANDASAN TEORI}




\section{A. Sistem Inventory}

Sistem inventory adalah suatu kegiatan dalam proses pengolahan data barang yang terdapat di dalam suatu gudang. Sistem inventory memiliki pengaruh besar terhadap suatu instansi, karena sistem inventory dapat membantu menyelesaikan masalah pengolahan data barang dan memudahkan pelaporan data barang yang tersedia(KurniawanDidik dkk, 2014:18).

Inventori merupakan sebuah konsep yangmencerminkan sumber daya yang dapat digunakan tetapi tidak atau belum dipergunakan.Pengertian inventori dapat diartikan dalambeberapa hal yang berbeda, antara lain(Rahmad Faisal dan Bagio Tony Hartono, 2016:2):

a. Stok yang tersedia pada saat itu juga.

b. Daftar perincian barang yang tersedia.

c. Untuk keuangan dan akunting.

Jumlah stok barang yang dimiliki oleh suatuorganisasi pada suatu waktu.Fungsi pokok dari inventori adalah memenuhisemua permintaan pelanggan dengan persediaanbarang yang seminimal mungkin. Namun kitatidak boleh melihat keuntungan yang diperolehnya dengan memperhatikan segi inventori daribagian gudang saja karena inventori berpengaruhdalam semua departemen yang ada dalam suatuperusahaan(Rahmad Faisal dan Bagio Tony Hartono 2016:2).

\section{B. Briket Batu Bara}

Briket batubara adalah bahan bakar padat dengan bentuk dan ukuran tertentu, yang tersusun dari butiran batubara halus yang telah mengalami proses pemampatan dengan daya tekan tertentu, agar bahan bakar tersebut lebih mudah ditangani dan menghasilkan nilai tambah dalam pemanfaatan. Syarat briket yang baik adalah briket yang permukaannya halus dan tidak meninggalkan bekas hitam di tangan.

Briket adalah teknologi yang menggunakan proses basah atau kering untuk mengkompresi bahan baku ke dalam beberapa bentuk. Proses briket kering memerlukan tekanan tinggi dan tidak memerlukan pengikat. Proses tersebut mahal dan direkomendasi hanya untuk produksi level tinggi. Sedangkan proses basah hanya memerlukan tekanan rendah tetapi memerlukan binder.

\section{Bahasa Pemrograman Visual Basic.Net}

Bahasa pemrograman visual basic.net dikembangkan oleh Microsoft. Bahasa Pemrograman Visual Basic.Net atau lebih dikenal dengan VB.NET merupakan salah satu bahasa pemrograman Komputer Tingkat Tinggi dan Salah Satu bahasa Pemrograman yang Object Oriented Program (OOP) atau pemrograman yang berorientasi pada object.

Kata pada"Visual" menunjukan cara yang digunaka nuntuk membuat Graphical User Interface (GUI) dimana user tidak perlu lagi menuliskan instruksi pemrograman dalam kode-kode barishanya untuk membuat sebuah Desain Form atau Aplikasi cukup melakukan Draganddrop object yang akan digunakan.

\section{MySQL}

Menurut (Setiawan,2007:56), SQL (Structure Query Language) adalah sebuah perangkat lunaksistem manajemenbasis dataSQLatau DBMS yang multithread, multiuser. Kehandalan suatu sistem basisdata dapat diketahui dari cara kerja pengoptimasinya dalam melakukan proses perintah SQL yang dibuat oleh pengguna 
programaplikasi. SQL mendukung operasi basisdata transaksional maupun nontransaksional.

\section{E. Konsep Perancangan Data Base}

Menurut Tim Devisi dan pengembangan Madcom (2006:3) Data base dapat diartikan sebagai sekumpulan data atau informasi yang terdiri atas satu atau lebih table-table yang saling berhubungan antara satu dengan yang lain, dimana anda dapat menambah,menganti,menghapus dan mengedit data dalam table-table tersebut.

\section{METODE PENELITIAN}

Adapun metode penelitian yang digunakan dalam penelitian ini adalah metode pengembangan sistem model waterfall, adapun langkah-langkah adalah :

1. Analisis sistem inventory.

2. Desain sistem perancangan sistem yang akan dibuat sesuai dengan kebutuhan perusahaan

3. Implementasi dan Pengujian Sistem, yakni pengujian sistem yang telah dirancang.

4. Integrasi dan testingmenjalan sistem yang sudah dibuat dan mencoba sistem tersebut

5. Operasi dan pemeliharaan sistem

\section{HASILDAN PEMBAHASAN}

Aplikasi Sistem Inventori Briket Batu Bara pada PT. Bengkulu Mandiri yang telah dirancang sesuai dengan proposal diberi nama App.BatuBara.Exe. Dimana aplikasi ini telah selesai dibuat dan dapat dipergunakan untuk membantu Sistem Inventori Briket Batu Bara pada PT. Bengkulu Mandiri dalam hal melakukan transaksi pembelian, produksi dan penjualan.

Aplikasi ini telah berhasil dibangun sesuai dengan kebutuhan yang diperlukan oleh sistem, sehingga aplikasi ini diharapkan mampu menunjang dan membantu pihak yang terkait dalam proses pengolahan data dan menghasilkan informasi yang cepat, efektif dan akurat.

\section{A. Implementasi dan Pembahasan Program}

Implementasi Sistem Inventori Briket Batu Bara pada PT. Bengkulu Mandiri ini dibuat dengan menggunakan bahasa pemrograman Visual Basic.Net Fasilitas yang terdapat pada aplikasi ini terdapat beberapa menu yaitu File, menu transaksi, menu laporan, menu Utility dan menu keluar. Pada menu File terdapat sub menu data barang, sub menu data barang. Sedangkan pada menu transaksi terdapat sub menu data penjualan. Pada menu laporan terdapat sub menu laporan data barang dan laporan per periode.

\section{Form Login Aplikasi}

Untuk dapat menggunakan atau mengoperasikan aplikasi ini, sistem akan meminta user untuk melakukan login. Halaman login akan tampil seperti gambar berikut ini 


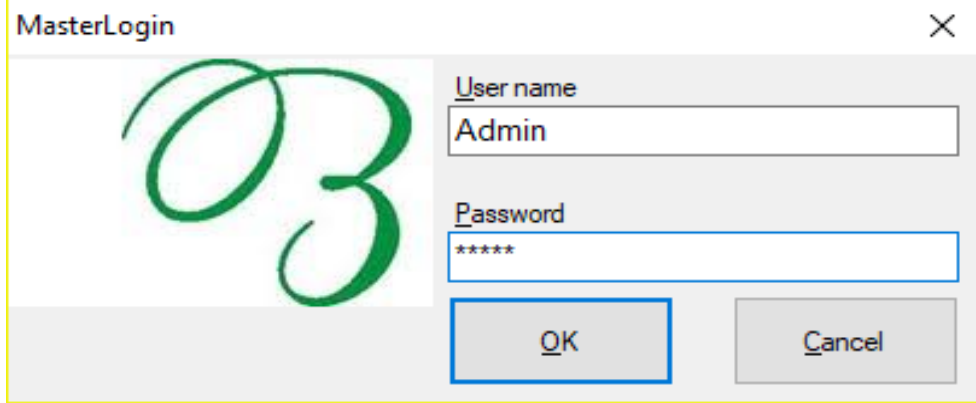

Gambar 1 Login Aplikasi

Pada form login ini user diminta untuk memasukkan Username, password dan status user.

\section{Menu File}

Pada menu file data terdapat beberapa sub menu yaitu sub menu data user, sub menu data bahan, sub menu data barang, sub menu data supplier, dan sub menu data konsumen.

\section{a. Sub Menu Data User}

Sub menu input data user merupakan form untuk melakukan entri data petugas yang terdapat pada aplikasi ini, untuk lebih jelas dapat dilihat pada gambar berikut ini :

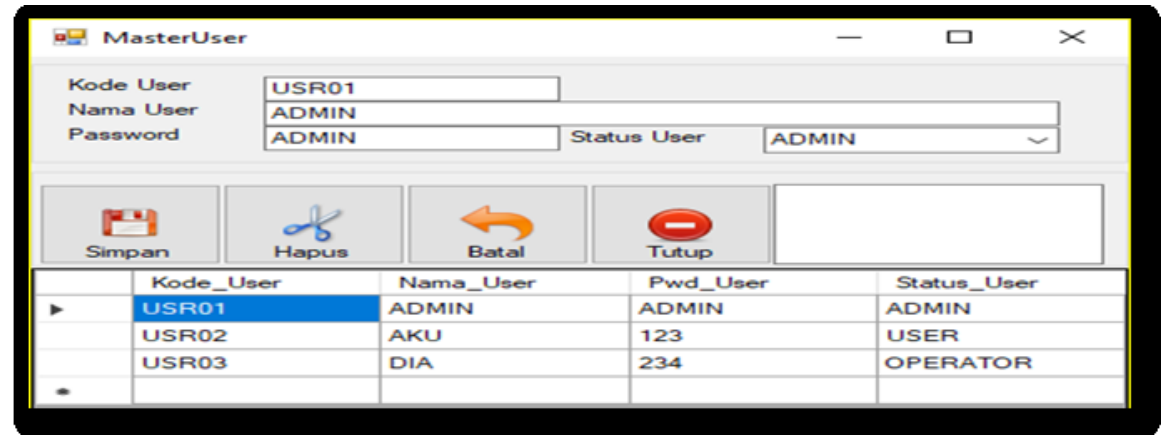

\section{Gambar 2. Input Data User}

\section{b. Sub Menu Data Bahan}

Sub menu input databahan merupakan form untuk melakukan entri data bahan yang terdapat pada aplikasi ini, untuk lebih jelas dapat dilihat pada gambar berikut ini

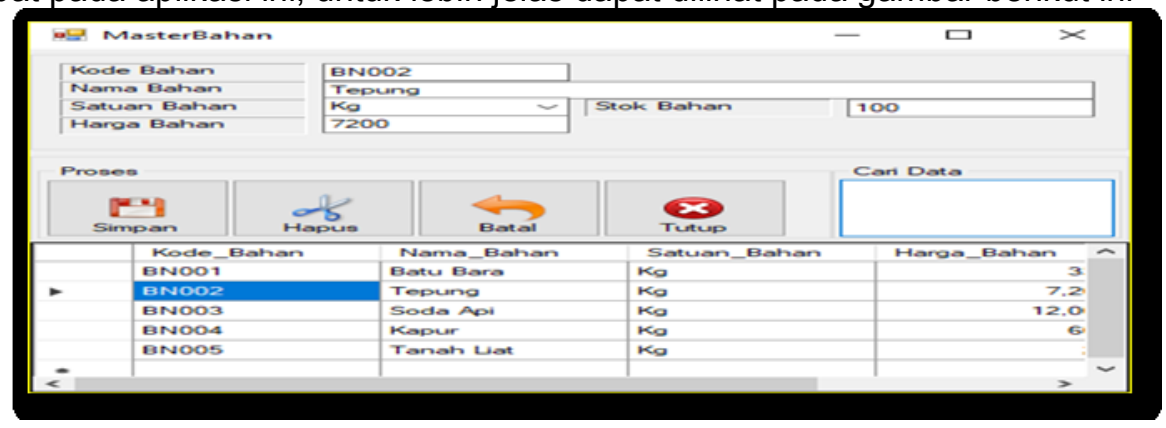

168 | Rute Adeya Saputra ${ }^{1)}$, Khairif), Ricky Zulfiandry'), Sistem Inventory Briket Batu Bara Pt.Mandiri.... 


\section{CATOT KACA गOURNAL}

\section{Gambar 3. Input Data Bahan}

\section{c. Sub Menu Data Barang}

Sub menu input databarang merupakan form untuk melakukan entri data barang yang terdapat pada aplikasi ini, untuk lebih jelas dapat dilihat pada gambar berikut ini :

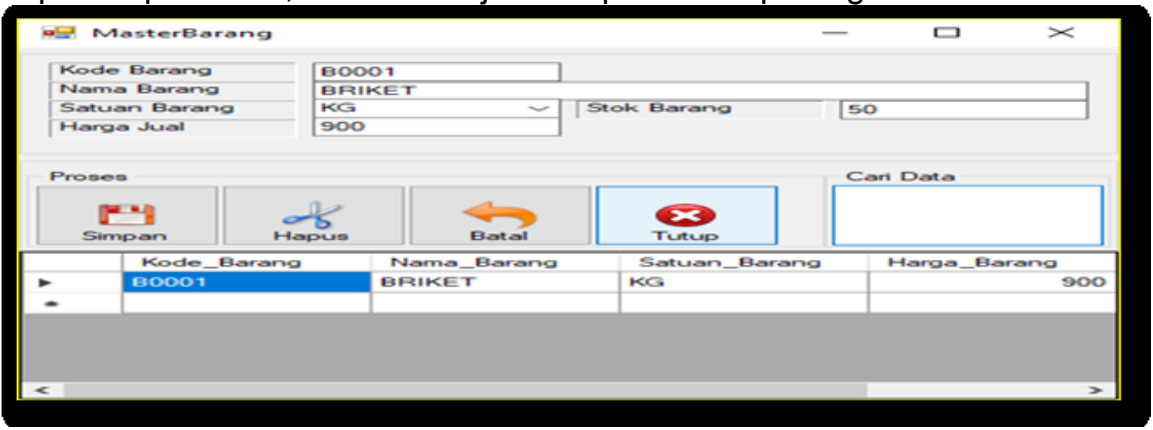

Gambar 4. Input Data Barang 
ISSN: $X \times 32-X$

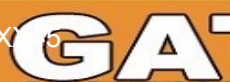

गOUีतNAL

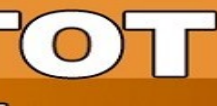

Jurnal Keilmuan Teknik: Aplikasi, Perencanaan, Rancang Bangun, Sistem, Simulasi, \& Rekayas

\section{d. Sub Menu Data Supplier}

Sub menu input data supplier merupakan form untuk melakukan entri data supplier yang terdapat pada aplikasi ini, untuk lebih jelas dapat dilihat pada gambar berikut ini :

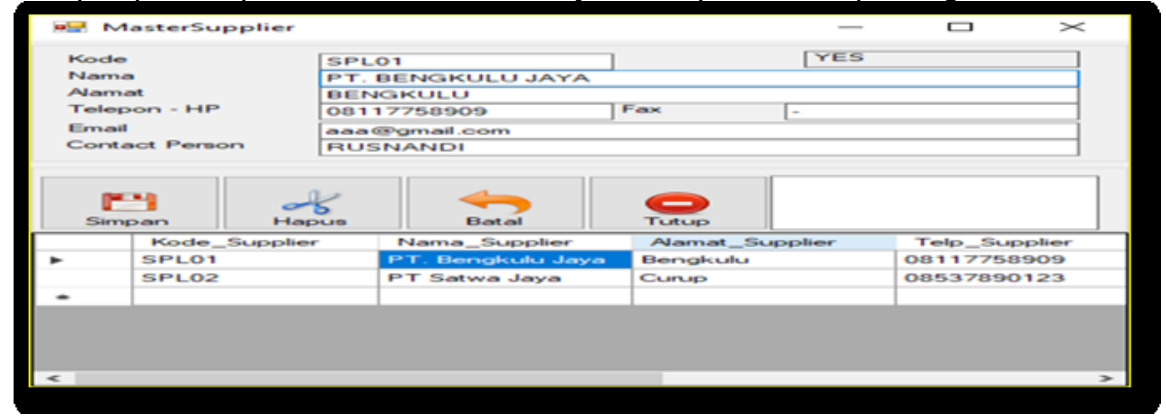

Gambar 5. Input Data Supplier

\section{e. Sub Meu Data Konsumen}

Sub menu input data supplier merupakan form untuk melakukan entri data supplier yang terdapat pada aplikasi ini, untuk lebih jelas dapat dilihat pada gambar berikut ini

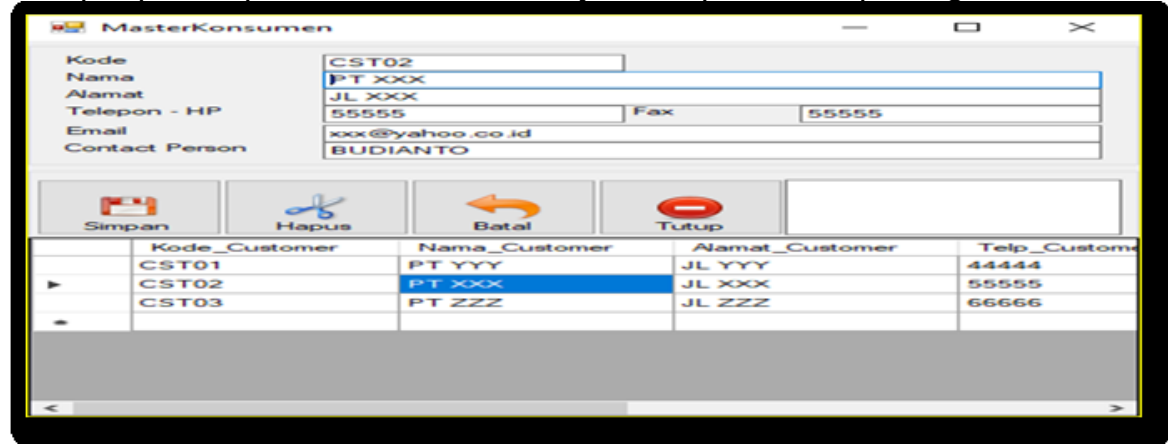

Gambar 6. Input Data Konsumen

\section{Menu Transaksi}

Pada menu transaksi terdapat beberapa sub menu yaitu sub menu pembelian, sub menu produksi, dan sub menu data penjualan

a. Sub Menu Transaksi Pembelian

Sub menu transaksi pembelian merupakan form untuk melakukan proses pembelian bahan baku kepada supplier untuk memproduksi briket yang terdapat pada PT. Bengkulu Mandir, untuk lebih jelas dapat dilihat pada gambar dibawah ini

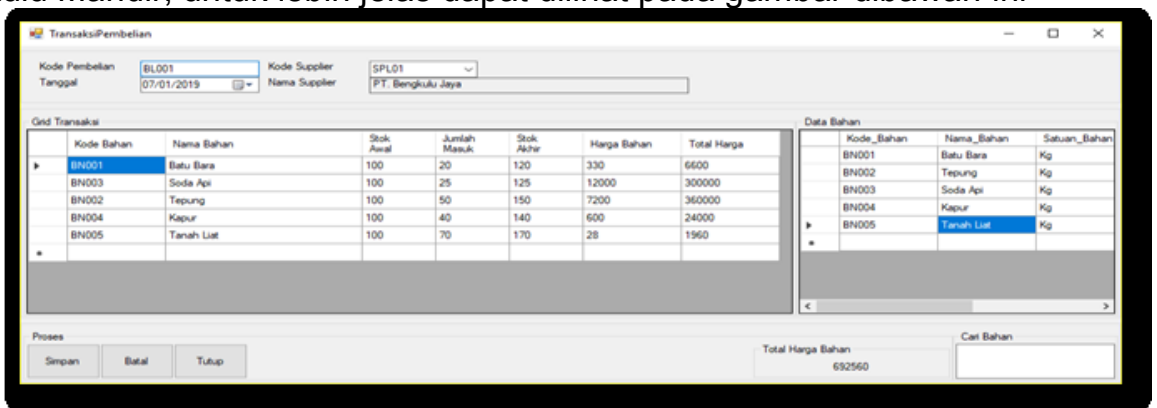

Gambar 7. Transaksi Pembelian Bahan Baku

170 | Rute Adeya Saputra1), Khairif), Ricky Zulfiandry²), Sistem Inventory Briket Batu Bara Pt.Mandiri..... 


\section{GATOR KACA

\section{b. Sub Menu Produksi}

Sub menu produksi merupakan form untuk melakukan proses produksi briket yang terdapat pada PT. Bengkulu Mandir, untuk lebih jelas dapat dilihat pada gambar dibawah ini :

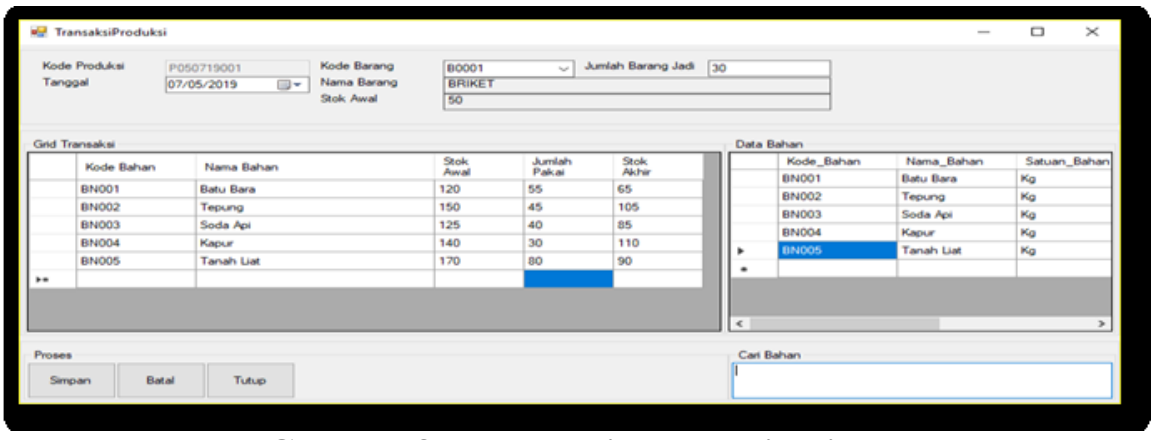

Gambar 8. Transaksi Produksi Briket

\section{c. Sub Menu Transaksi Penjualan}

Sub menu transaksi penjualan merupakan form untuk melakukan proses penjualan briket kepada konsumen briket yang terdapat pada PT. Bengkulu Mandir, untuk lebih jelas dapat dilihat pada gambar dibawah ini :

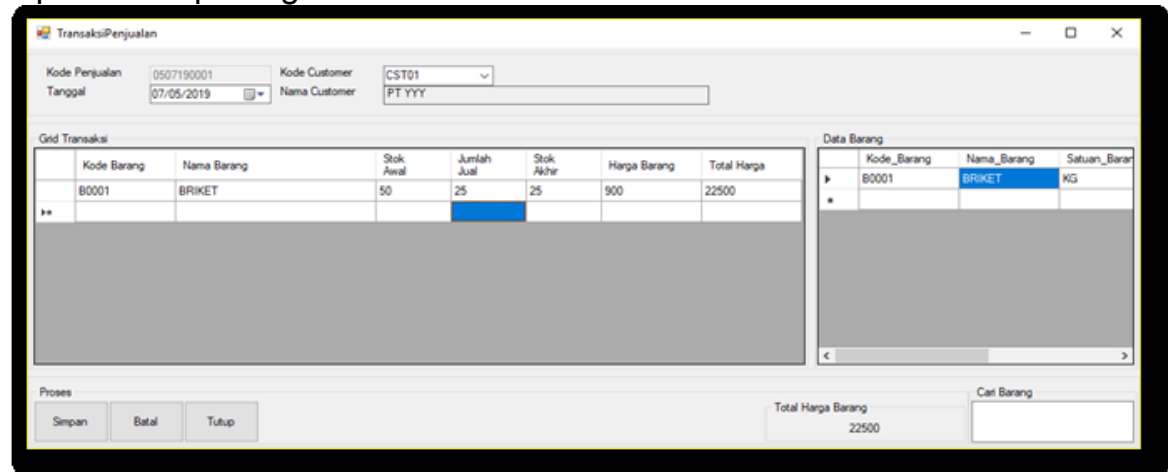

\section{Gambar 9. Transaksi Penjualan Briket}

\section{Menu Laporan}

Pada menu laporan ini terdapat enam sub menu yaitu sub menu laporan master, sub menu laporan pembelian, sub menu laporan produksi, sub menu laporan penjualan, sub menu laporan bahan baku dan sub menu laporan barang

\section{a. Laporan Data Barang}

Sub menu laporan data barang yaitu laporan laporan untuk menampilkan semua data barang beserta dengan jumlah barang yang terdapat pada PT. Bengkulu Mandiri, seperti terlihat pada gambar berikut ini : 

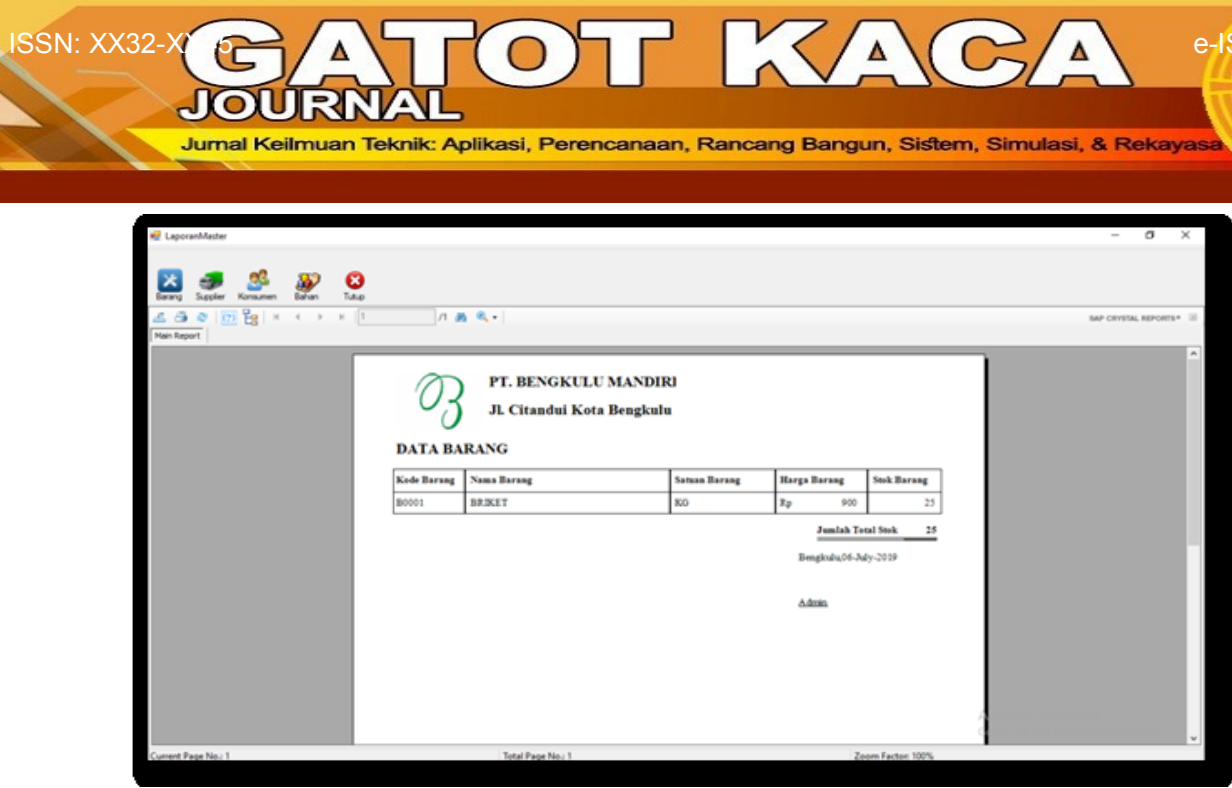

Gambar 10. Laporan Data Barang

\section{b. Laporan Data Supplier}

Sub menu laporan data supplier yaitu laporan laporan untuk menampilkan semua data supplier yang ada pada PT. Bengkulu Mandiri, seperti terlihat pada gambar berikut ini :

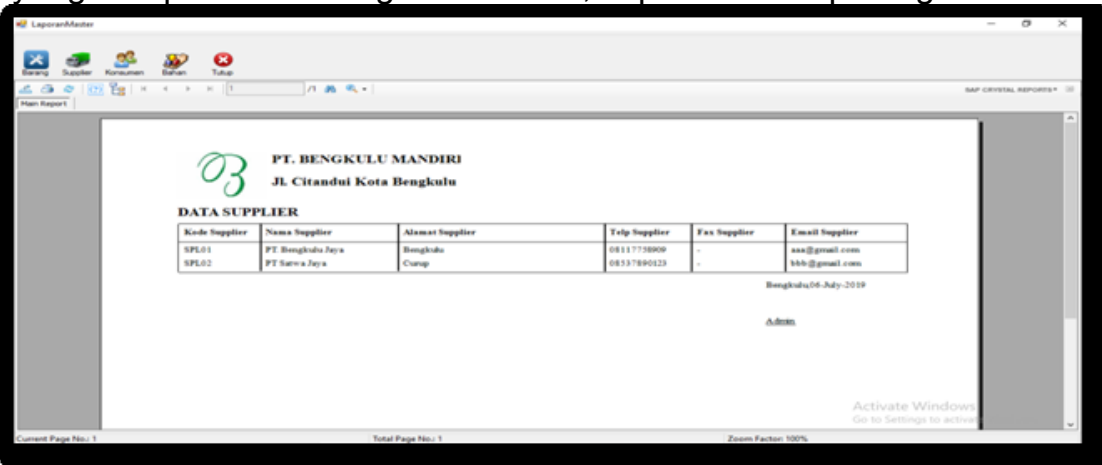

Gambar 11. Laporan Data Supplier

\section{c. Laporan Data Konsumen}

Sub menu laporan data konsumen yaitu laporan laporan untuk menampilkan semua data konsumen yang ada pada PT. Bengkulu Mandiri, seperti terlihat pada gambar berikut ini

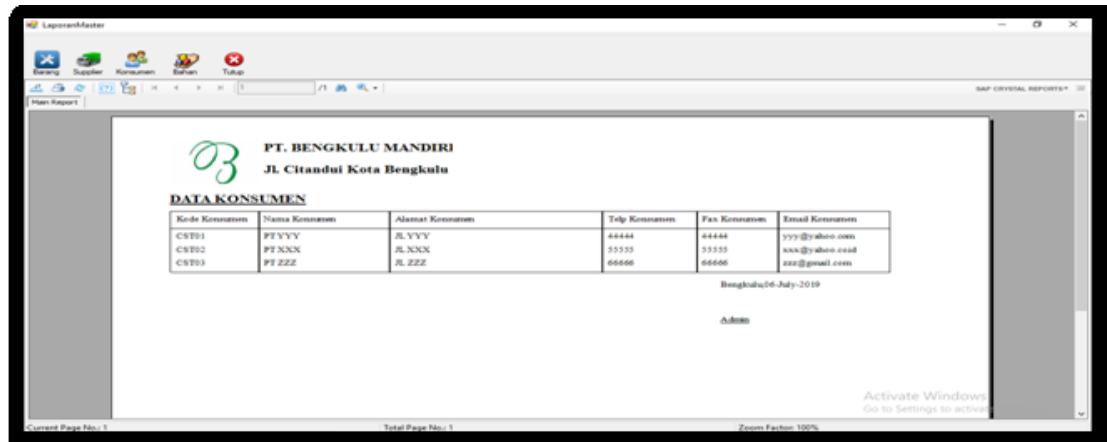

Gambar 12. Laporan Data Konsumen

172 | Rute Adeya Saputra1), Khairif), Ricky Zulfiandry²), Sistem Inventory Briket Batu Bara Pt.Mandiri.... 


\section{d. Laporan Data Bahan Baku}

Sub menu laporan data bahan baku yaitu laporan laporan untuk menampilkan semua data bahan baku yang ada pada PT. Bengkulu Mandiri, seperti terlihat pada gambar berikut ini

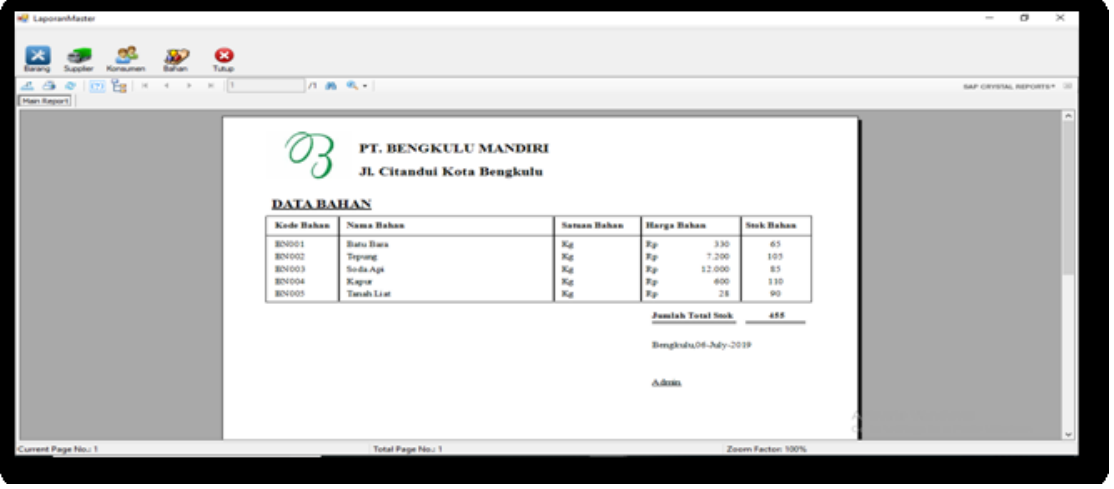

\section{Gambar 13. Laporan Data Bahan Baku}

\section{e. Sub Menu Laporan Data Pembelian}

Sub menu laporan pembelian ini terdiri dari empat yaitu laporan harian, laporan per periode, laporan bulanan dan laporan tahunan. Untuk menampilkan data laporan periode user diminta untuk memilih dari tanggal dan sampai tanggal seperti terlihat pada gambar berikut ini

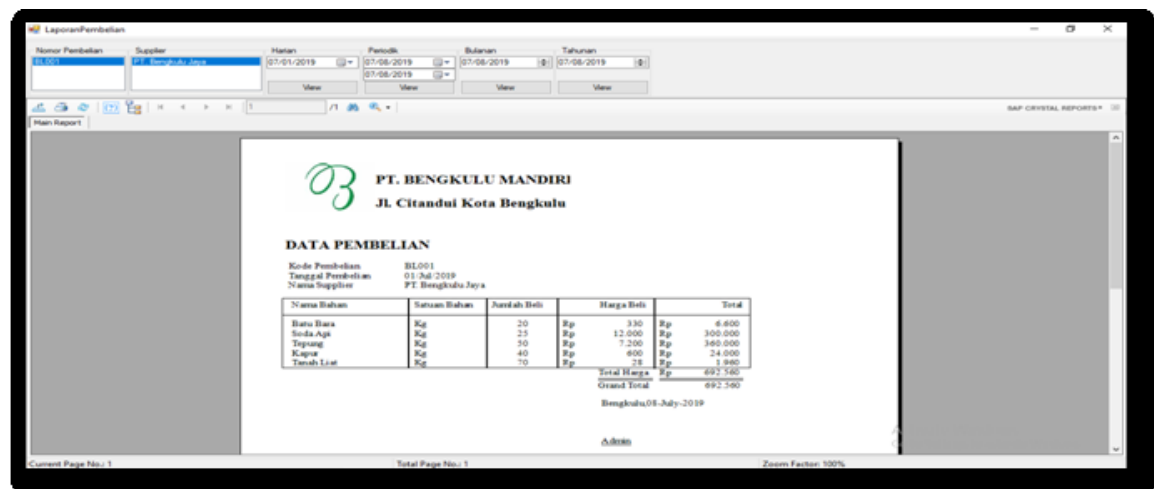

\section{Gambar 14. Hasil Laporan Pembelian Harian}

\section{f. Sub Menu Laporan Produksi}

Sub menu laporan produksi ini terdiri dari empat yaitu laporan harian, laporan per periode, laporan bulanan dan laporan tahunan. Untuk menampilkan data laporan periode user diminta untuk memilih dari tanggal dan sampai tanggal seperti terlihat pada gambar berikut ini 


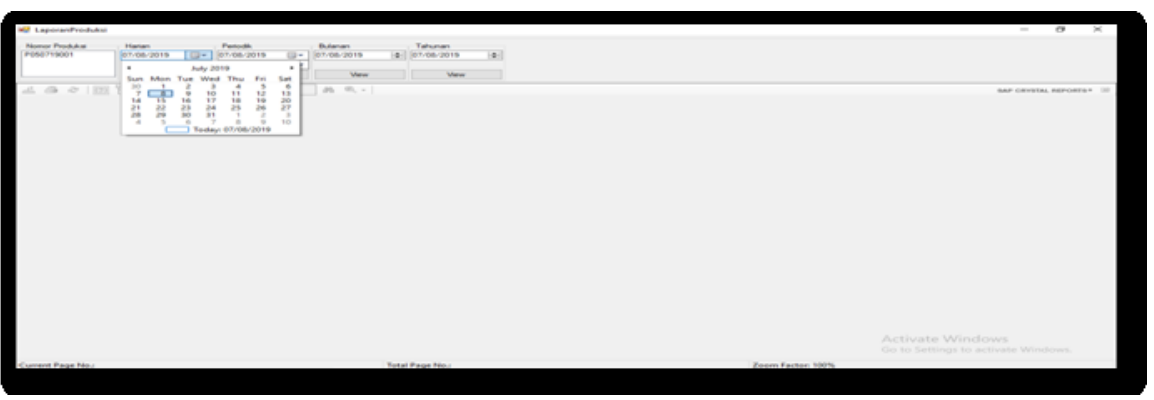

Gambar 15. Laporan Harian Data Produksi

\section{g. Menu Laporan Penjualan}

Sub menu laporan penjualan ini terdiri dari empat yaitu laporan harian, laporan per periode, laporan bulanan dan laporan tahunan. Untuk menampilkan data laporan periode user diminta untuk memilih dari tanggal dan sampai tanggal seperti terlihat pada gambar berikut ini

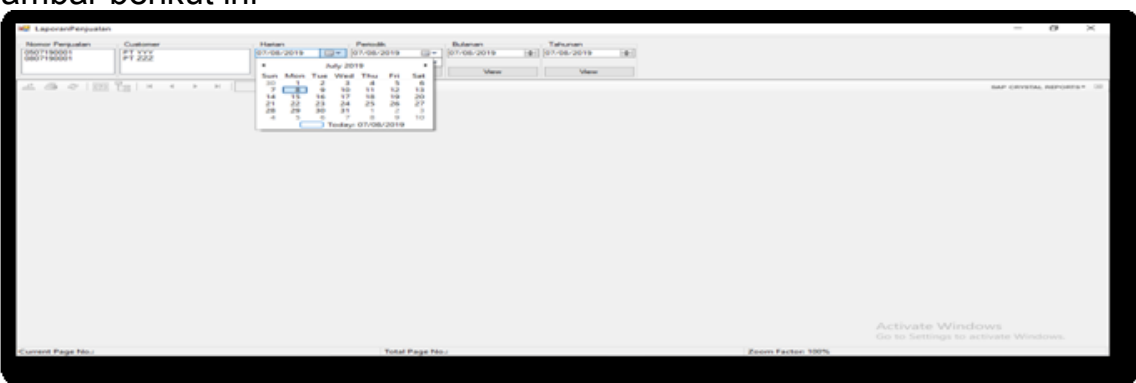

Gambar 16. Laporan Harian Data Penjualan

\section{Sub Menu Laporan Stok Bahan Baku}

Sub menu laporan stok bahan baku ini terdiri dari empat yaitu laporan stok harian per bahan baku, laporan stok periode per bahan baku, laporan stok bulanan per bahan baku dan laporan stok semua bahan baku per bulan.

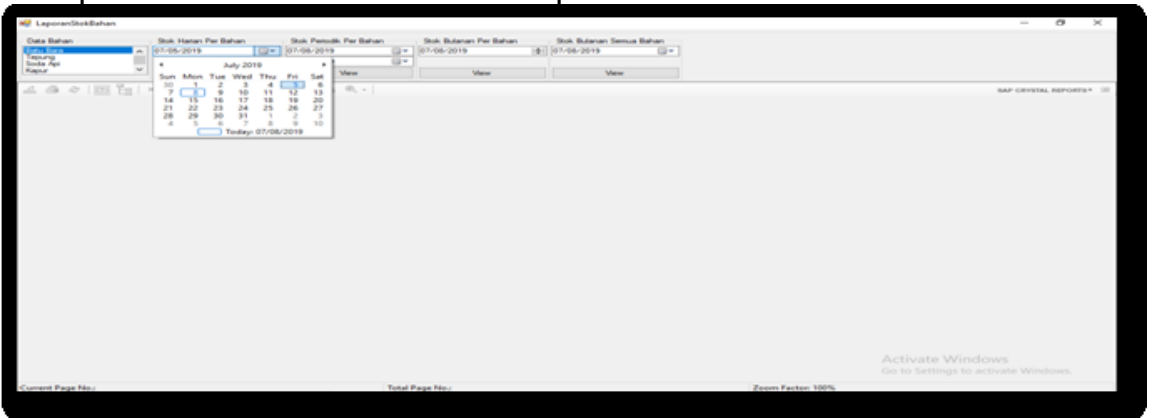

Gambar 17. Laporan Stok Bahan Baku Per Hari

\section{B. Pengujian Sistem}

Pengujian yang dilakukan pada aplikasi ini adalah dengan menggunakan teknik black box, seperti yang telah dijelaskan pada Bab III sebelumnya. Teknik black box ini merupakan teknik pengujian yang berfokus pada keluaran hasil dari respon, atau secara simpel untuk mengetahui apakah ada error atau ada fungsi yang tidak berjalan 


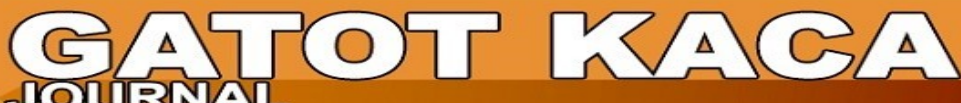

sesuai dengan harapan. Tujuan dari pengujian ini adalah untuk menjamin bahwa perangkat lunak yang dibangun memiliki kualitas yang handal, yaitu mampu mempresentasikan kajian pokok dari spesifikasi analisis, perancangan dan pengkodean dari perangkat lunak itusendiri. Berikut tabel pengujian black box.

Tabel 1. Pengujian Black Box

\begin{tabular}{|l|c|c|}
\hline \multicolumn{1}{|c|}{ Jenis Uji } & Keterangan Uji & Jenis Pengujian \\
\hline Login User & Pengecekan User terdaftar pada database & Black Box \\
\hline \multirow{4}{*}{ Input Data } & Input Data User & Black Box \\
\cline { 2 - 3 } & Input Data Bahan Baku & Black Box \\
\cline { 2 - 3 } & Input Data Barang & Black Box \\
\cline { 2 - 3 } & Input Data Supplier & Black Box \\
\cline { 2 - 3 } & Input Data Konsumen & Black Box \\
\hline \multirow{3}{*}{ Proses Transaksi } & Transaksi Pembelian & Black Box \\
\cline { 2 - 3 } & Proses Produksi & Black Box \\
\cline { 2 - 3 } & Transaksi Penjualan & Black Box \\
\hline
\end{tabular}

Tabel 2. Pengujian Login

\begin{tabular}{|l|l|l|l|}
\hline \multicolumn{5}{|c|}{ Kasus dan Hasi Uji (Data Normal) } \\
\hline Data Masukan & Yang diharapkan & Pengamatan & Kesimpulan \\
\hline $\begin{array}{l}\text { Username : Admin } \\
\text { Password : admin }\end{array}$ & $\begin{array}{l}\text { Dapat masuk ke menu } \\
\text { utama dari aplikasi. }\end{array}$ & $\begin{array}{l}\text { Dapat masuk ke } \\
\text { tampilan menu utama }\end{array}$ & $\begin{array}{l}{[\mathrm{x}] \text { diterima }} \\
{[\text { ] ditolak }}\end{array}$ \\
\hline \multicolumn{4}{|c|}{ Kasus dan Hasi Uji (Data Salah) } \\
\hline \multicolumn{1}{|c|}{ Data Masukan } & Yang diharapkan & Pengamatan & $\begin{array}{l}\text { Kesimpula } \\
\text { n }\end{array}$ \\
\hline $\begin{array}{l}\text { Username : admin } \\
\text { Password : 55555 }\end{array}$ & $\begin{array}{l}\text { Tidak dapat masukke } \\
\text { dalam sistem }\end{array}$ & $\begin{array}{l}\text { Menampilkan pesan } \\
\text { "Login Gagal" }\end{array}$ & $\begin{array}{l}{[\mathrm{x}] \text { diterima }} \\
{[\text { ] ditolak }}\end{array}$ \\
\hline
\end{tabular}

\section{KESIMPULAN DAN SARAN}

\section{Kesimpulan}

Berdasarkan dari hasil penulisan mengenai sistem inventori briket batu bara yang dilakukan di PT. Bengkulu Mandiri, dapat diambil kesimpulan bahwa:

1. Dengan adanya aplikasi inventori briket batu bara ini dapat mengefektifitaskan kinerja staf dibagian adminstrasi dalam proses pengelolaan inventori briket batu bara di PT. Bengkulu Mandiri.

2. Proses pengelolaan mulai dari pembelian bahan baku, memproduksi hingga penjualan lebih mudah di kontrol dan efisien sehingga mampu memaksimalkan semua hasil produksi dan penjualan yang akan menguntungkan PT. Bengkulu Mandiri.

\section{Saran}

Aplikasi aplikasi inventori briket batu bara yang telah dibuat ini terbuka untuk dapat dikembangkan lagi oleh penulis lain pada tahap penulisan selanjutnya. Terdapat beberapa saran bagi penulisselanjutnya berkaitan dengan pengembangan sistem aplikasi inventori briket batu bara ini yaitu perlunya pengadaan sarana dan prasarana yang menunjang dalam pemakaian aplikasi ini, seperti adanya fasilitas hardware dan software yang akan menunjang pemakaian aplikasi perpustakaan ini serta dikembangkan berbasis jaringan sehingga pengelolaan transaksi lebih terpusat. 


\section{DAFTAR PUSTAKA}

Fatta, 2007. Analisis dan Perancangan Sistem Informasi. Yogyakarta : Andi Offset Herlambang dan Tanuwijaya, 2005. Sistem Informasi : Konsep, Teknologi dan Manajemen. Yogyakarta : Graha IImu

I Gusti Suryantara, 2014. MerancangAplikasi Akuntansi dengan VB.Net. PT. Alex Komputindo, Jakarta.

Didik Kurniawan, 2014. Sistem Inventory Jurusan IImu Komputer Di Universitas Lampung. Fakultas MIPA UNILA : Lampung.

Rusdah, 2011. Analisi dan Rancangan Sistem Informasi Persediaan. Jakarta.

Tony Hartono Bagio dan Faisal Rahmad. Sistem Informasi Inventory dengan Menggunakan Metode Frist In Frist Out (FIFO). Fakultas IImu Komputer Narotama : Surabaya.

Setiawan, 2007. Mudah Tepat Singkat Pemrograman HTML Standarisasi, Konfigurasi, dan Implementasi. Bandung : Yrama Widya.

Ladjamudin, 2010. Analisis dan Perancangan Sistem Informasi dengan Metodologi Berorentasi Objek. Teknik Informatika : Bandung

James, D S, Eart, K S, Skousen, K F, 2007. Akuntansi Keuangan (Intermediate Accounting). Penerbit Salemba Empat : Jakarta

Madcom, 2006. Belajar Data Base Menggunakan MySQL. Andi Offset : Yogyakarta 